\title{
Effects of institutional support on innovation and performance: Roles of dysfunctional competition
}

\begin{abstract}
Purpose This study aims to empirically investigate the effects of institutional support on product and process innovation and firm performance and describe how dysfunctional competition influences relevant outcomes.

Design/methodology/approach This study develops a research model based on institution-based view and tests it using structural equation modeling and empirical data collected from 300 manufacturers in China.

Findings The results show that institutional support positively affects product and process innovation and firm performance. Both product and process innovation improve firm performance. The findings reveal that dysfunctional competition significantly reduces the positive effects of institutional support on product and process innovation but leaves the effects of institutional support and product and process innovation on firm performance unaffected.

Originality/value This study contributes to innovation literature by providing insights into the impact of China's institutional environment on manufacturing firms' product and process innovation decisions. The findings also contribute to institution-based view literature by providing empirical evidence on the joint effects of institutional support and dysfunctional competition on product and process innovation and firm performance. This study can help manufacturers in China take advantage of institutional environment and adjust product and process innovation decisions accordingly.
\end{abstract}

Keywords: institutional support; dysfunctional competition; innovation; performance; China 


\section{Introduction}

Chinese manufacturing firms have made remarkable achievements on both product and process innovation (Zhang et al., 2015). For example, China now ranks the first worldwide in terms of the number of patent applications by residents and has had the fastest annual growth in the world for several years (World Intellectual Property Organization, 2015). The Chinese government plays a major role in promoting innovation by providing institutional support (Li and Zhang, 2007; Sheng et al., 2013; Zhang et al., 2015). For example, national investment in science and technology accounted for $4.4 \%$ of the government's annual financial expenditure in 2014 (National Bureau of Statistics, 2014). The Chinese government has also introduced policies to transform China into a knowledge-based economy and improve firms' independent innovation in the 15-year medium-to-long-term plan for the development of science and technology (2006-2020) (Parayil and D'Costa, 2009). Institutional support refers to the extent to which government and its agencies give support to firms in order to mitigate the negative effects of inadequate institutional infrastructure ( $\mathrm{Li}$ and Atuahene-Gima, 2001). Support from the government and its agencies can provide firms with low-cost resources (Qian et al., 2013) and reduce policy uncertainty (Peng et al., 2009) and so promote innovation (Li and Atuahene-Gima, 2001; Qian et al., 2013). However, empirical findings of the effectiveness of institutional support have been inclusive, and some studies show no positive relationship between institutional support and innovation (Sheng et al., 2011; Shu et al., 2015).

China's institutional environment is also characterized by legal inadequacy and enforcement inefficiency (Sheng et al., 2013; Wang et al., 2011; Wang et al., 2015). Firms may suffer from patent and copyright violation, widespread copying of original inventions, and breaches of contract and other agreements (Zhao, 2006; Zhou and Poppo, 2010). This institutional environment leads to dysfunctional competition, which refers to the extent to which firms' competitive behavior is unfair or unlawful, such as copyright and patent infringement ( $\mathrm{Li}$ and Atuahene-Gima, 2001). In this way, dysfunctional competition may negatively affect firms' capabilities to profit from new 
products and processes ( $\mathrm{Li}$ and Atuahene-Gima, 2001; Li and Zhang, 2007; Li and Li, 2009) and attenuate the effectiveness of institutional support (Guo et al., 2014; Lu et al., 2008). The institutional environment in China thus may have mixed effects on manufacturing firms' product and process innovation (Parayil and D'Costa, 2009; Zhou and Poppo, 2010; Qian et al., 2013). However, there is limited empirical evidence on how the effects of institutional support on product and process innovation and firm performance are influenced by dysfunctional competition.

This study aims to empirically investigate the joint effects of institutional support and dysfunctional competition on product and process innovation and firm performance in China. It focuses on two research questions. First, how does institutional support affect product and process innovation and firm performance? Second, how does dysfunctional competition moderate these relationships? The findings of this study can benefit researchers, practitioners, and policy makers. In particular, it extends current knowledge of the impact of institutional environment on product and process innovation and firm performance, contributing to innovation and institution-based view literature. The findings can also help managers develop a better understanding of the institutional environment in China and adapt innovation strategies and practices accordingly. In addition, this study can offer guidelines to policy makers in the Chinese government to devise programs and regulations to promote innovation and development.

\section{Theoretical background and hypotheses}

\subsection{Institutional support}

Institutional support is a general reflection of financial and technical support from government and its agencies, which provide firms with critical resources that they may use for innovation and development (Li and Atuahene-Gima, 2001; Sheng et al., 2013; Shu et al., 2015). Support from the government and its agencies allows firms to interpret policies and program correctly, decreasing environmental uncertainty (Peng, 2003; Ma et al., 2014; Zhang et al., 2015). Researchers argue that institutional support plays an important role in Chinese firms' innovation strategies (Guo et al., 2014; Qian 
et al., 2013; Sheng et al., 2011; Shu et al., 2015). However, empirical studies have reported mixed findings on the effectiveness of institutional support. For example, Li and Atuahene-Gima (2001) find that institutional support positively influences product innovation and performance. Sheng et al. (2011) discover that institutional support reduces the effects of political ties on firm performance. Hence, there is a tangible need to identify the mechanisms through which institutional support affects innovation and firm performance.

\subsection{Dysfunctional competition}

Dysfunctional competition reflects managers' perception of legal protection against opportunistic or illegal activities in the market (Sheng et al., 2013; Li and Zhang, 2007). It can drive firms to take action to respond to challenges in institutional environment. Researchers argue that dysfunctional competition hampers firms' capability to fully reap the potential benefits of innovation and negatively influences their performance ( $\mathrm{Li}$ and Atuahene-Gima, 2001; Li and Li, 2009). For example, Li and Zhang (2007) find that dysfunctional competition can reduce the positive effects of managers' functional experiences on the performance of new ventures. Sheng et al. (2013) report that dysfunctional competition influences the effects of the speed of new product development on firm performance. However, there is limited empirical evidence on how dysfunctional competition affects the effectiveness of institutional support.

\subsection{Product and process innovation}

Innovation refers to new applications of knowledge, ideas, methods, and skills that can leverage a firm's competitiveness (Tellis et al., 2009; Ho, 2011; Ruiz-Jiménez and Fuentes-Fuentes, 2013). The innovation subject can be either a product or a process (Gunday et al., 2011; Un and Asakawa, 2015). Product innovation refers to the new products introduced to meet market demands and increase profits (Damanpour, 2010). Process innovation can be defined as the new techniques and processes introduced into operations that help to promote efficiency or effectiveness, and lower the costs of production and delivery (Un and Asakawa, 2015; Gunday et al., 2011). There is empirical evidence that product and process innovation 
are positively associated with firm performance and can bring firms sustainable competitive advantages (Schoenherr and Swink, 2015; Kostopoulos et al., 2011; Tellis et al., 2009; Ho, 2011). Researchers argue that product and process innovation have different objective and competitive impact (Un and Asakawa, 2015). However, the majority of existing empirical studies on the impact of institutional environment on innovation have focused only on product innovation (Guo et al., 2014; Li and Atuahene-Gima, 2001; Wang et al., 2011; Ma et al., 2014). Hence, empirically investigating the joint effects of institutional support and dysfunctional competition on process innovation and comparing the findings with those of product innovation can contribute to innovation literature (Damanpour, 2010; Un and Asakawa, 2015).

\subsection{Institution-based view}

Institution-based view emphasizes dynamic interactions between institutions and organizations and views organizational behavior and strategic choices as the outcomes of these interactions (Peng, 2002; Peng et al., 2009). This view has been widely used to investigate how institutions affect firms' decisions and performance (Peng et al., 2008; Peng et al., 2009; Peng, 2013; Fuentelsaz et al., 2015) and so provides a theoretical foundation for this study. Institutions set legitimate requirements for and provide external resources supporting firms' operations (Fuentelsaz et al., 2015; Lu et al., 2008; Peng et al., 2009; Peng, 2013). Firms' strategic choices are made within institutional constraints (Peng, 2003). In particular, formal and informal institutions form a compensatory infrastructure that advises firms of which strategic choices are acceptable and supportable (Peng, 2002). Informal institutions play a bigger role when formal ones are unclear or fail (Peng et al., 2009). Institution-based view argues that institutions directly determine strategy formulation and implementation (Peng, 2002) and managers pursue their rational interests and make decisions within a given institutional framework (Peng, 2006). Given China's underdeveloped market mechanisms, institutions play a significant role in influencing Chinese firms' behavior and decisions (Guo et al., 2014; Sheng et al., 2015).

\subsection{Hypotheses}

Drawing on the institution-based view, it is here argued that institutional support 
motivates Chinese firms to invest in product and process innovation because the Chinese government has designed policies and programs to signal firms that innovation is legitimate (Parayil and D'Costa, 2009; Peng, 2006). Firms with competitive advantages in new product and process development are rewarded by the government (Sheng et al., 2013) and their success inspires other firms to model themselves after the innovators and make more investments in innovation (Peng, 2003). Institutional support also allows firms to access critical resources provided by the government, which helps them innovate and improve operations, which in turn improve performance ( $\mathrm{Li}$ and Zhang, 2007). In addition, managers' decisions are constrained by institutional environment (Peng et al., 2008). High levels of dysfunctional competition indicates that it is difficult for firms to protect their intellectual property rights and that their product and process innovation will be easily copied or imitated by competitors (Li and Atuahene-Gima, 2001). The innovators then are not able to fully capture the profits generated by their inventions. Hence, we argue that dysfunctional competition reduces the positive impact of product and process innovation on firm performance. Moreover, high levels of dysfunctional competition indicate that managers may be behaving opportunistically and misusing institutional support earmarked for innovation and development for personal interests. It also becomes difficult for government officials to devise effective policies and supportive programs (Peng, 2006). For this reason, we argue that dysfunctional competition attenuates the effects of institutional support on product and process innovation and firm performance. The conceptual model is shown in Figure 1.

Insert Figure 1 here

\subsubsection{The effects of institutional support on product and process innovation}

We argue that institutional support plays a significant role in promoting product and process innovation. China lacks market-supporting institutions, and the rules for market competition remain unpredictable and unclear (Wang et al., 2011; Zhou and Poppo, 2010). Support from the government has become an important tool for firms to deal with market uncertainty ( $\mathrm{Li}$ and Atuahene-Gima, 2001), and it has significantly 
influence on Chinese manufacturers' long-term strategy and investment decisions (Peng et al., 2008). Product innovation is a resource-consuming activity and poses many challenges to manufacturers because of the lack of financial and technical resources, poor management skills and capabilities, and uncertain business and institutional environments (Guo et al., 2014; Sheng et al., 2013). Institutional support provides critical external resources that foster the development of new products and favorable policies and regulations that protect intellectual property rights, and rewards innovators by granting legitimacy (Ma et al., 2014; Li and Atuahene-Gima, 2001; Shu et al., 2015; Peng et al., 2009). Hence, institutional support motivates firms to invest in and improves their capabilities for product innovation ( $\mathrm{Lu}$ et al., 2008; Guo et al., 2014; Shu et al., 2015).

Process innovation is a complex and risky activity that requires tacit knowledge and experienced employees (Un and Asakawa, 2015; Damanpour, 2010). The technical information and support provided by the government and imported advanced technologies allow Chinese manufacturers to learn skills and knowledge from foreign competitors (Morgan and Berthon, 2008), which can significantly improve process innovation (Shu et al., 2015). Using financial support from the government, Chinese companies can adopt new facilities and equipment and hire global talent, which allow them to implement advanced processes designs used by foreign competitors and develop new processes to improve the efficiency and effectiveness of production and delivery operations (Qian et al., 2013; Shu et al., 2015). Thus, we propose the following hypotheses:

Hla: Institutional support is positively associated with product innovation.

H1b: Institutional support is positively associated with process innovation.

\subsubsection{The effect of institutional support on firm performance}

The Chinese government and its agencies actively participate in business planning and guide economic activities, giving them an important role in firms' operations and strategic decisions (Cai et al., 2010; Zhou and Poppo, 2010). Institutional support indicates that the government and its agencies favor specific firms (Peng, 2002; Guo et al., 2014), so the firms can receive external financial and 
technical resources at little cost (Sheng et al., 2011). These resources can help the firms learn technologies from advanced competitors, enabling the firms to optimize production and supply chain operations and improve performance (Cai et al., 2010; Shu et al., 2015). Institutional support also allows firms to develop a better understanding of policies and predict their trends, which help them prepare for changes in business and institutional environments and adjust long-term strategies accordingly (Li and Atuahene-Gima, 2001; Shu et al., 2015). Institutional support also provides favorable policies and regulations, which enable firms to access to a wider range of strategic choices, such as entering new markets or obtaining exclusive licenses, which bring competitive advantages (Guo et al., 2014; Sheng et al., 2013). Thus, we propose the following hypothesis:

H2: Institutional support is positively associated with firm performance.

\subsubsection{The effects of product and process innovation on firm performance}

Researchers argue that product and process innovation provide first-mover advantages and superior profitability (Lu et al., 2015; Tellis et al., 2009; Gunday et al., 2011; Walker, 2004). In particular, the novelty of new products allows firms to charge a premium over competitors' products, increasing revenue and profits (Kostopoulos et al., 2011; Gunday et al., 2011; Schoenherr and Swink, 2015). The new features, improvements, or benefits associated with new products can also improve customer satisfaction, attract new customers, and develop new market segments, improving sales and performance (Morgan and Berthon, 2008; Kuo, 2013). By introducing new elements to production materials, machinery, equipment, task specifications, and workflow mechanisms, process innovation reduces operational costs and improves quality, flexibility, speed, and delivery (Damanpour, 2010; Un and Asakawa, 2015). Process innovation also helps a firm improve the nature of the operation and supply chain processes, increasing productivity and firm performance. Thus, we propose the following hypotheses:

H3a: Product innovation is positively associated with firm performance.

H3b: Process innovation is positively associated with firm performance. 2.5.4 The moderating effects of dysfunctional competition 
The institution-based view argues that managers' decisions are constrained by institutional environment (Peng, 2006). Managers take the influences of dysfunctional competition, which is a noteworthy feature of China's institutional environment, into account when they make strategic decisions (Sheng et al., 2013; Zhou and Poppo, 2010; Peng, 2013). High levels of dysfunctional competition indicate that firms frequently face unlawful or unfair competitive behavior in markets (Sheng et al., 2013; $\mathrm{Li}$ and Li, 2009). Dysfunctional competition also increases market uncertainty and risks because opportunistic behavior is not severely punished, and so it counteracts institutional support (Peng et al., 2009; Lu et al., 2008). In particular, because it is difficult for firms to protect their intellectual property rights and profit from innovations ( $\mathrm{Li}$ and Atuahene-Gima, 2001), they become unwilling to invest in new product and process development even if the government encourages them to do so (Cai et al., 2010). They may behave opportunistically by using the support acquired from government in other areas rather than innovation. When dysfunctional competition is intense, it also prevents government officials from acquiring accurate market information (Shu et al., 2015). This makes it harder for them to devise effective policies and programs to support firms' innovation and development. Hence, we argue that dysfunctional competition reduces the effects of institutional support on product and process innovation and firm performance. In addition, firms are faced with high risks of imitation and knowledge spillovers or leakage when dysfunctional competition is intense ( $\mathrm{Li}$ and Zhang, 2007; Li and Li, 2009). The efficacy of legal mechanisms of protection is also low and hence innovators may not be able to become principal beneficiaries of product and process innovation (Guo et al., 2014; Zhao, 2006). Hence, we argue that dysfunctional competition reduces the effects of product and process innovation on firm performance. Thus, we propose the following hypotheses:

H4a: Dysfunctional competition reduces the effect of institutional support on product innovation.

H4b: Dysfunctional competition reduces the effect of institutional support on process innovation. 
H4c: Dysfunctional competition reduces the effect of institutional support on firm performance.

H4d: Dysfunctional competition reduces the effect of product innovation on firm performance.

H4e: Dysfunctional competition reduces the effect of process innovation on firm performance.

\section{Research methods}

\subsection{Sample and data collection}

The sample was selected from three economic zones (i.e. Pearl River Delta, Yangtze River Delta, and Circum-Bohai Economic Zone) in China (Flynn et al., 2010; Qi et al., 2011). There are two reasons that the three regions are selected. First, the three economic zones are the most developed regions in China. There exists severe competitions and great governmental supports at the same time. Second, firms located in these three regions are inclined to compete through innovation (Zhang et al., 2015). They can represent the most innovative companies in China. The high-tech industries in the three regions are targeted because innovation is strategically important in these industries.

The questionnaire was originally developed in English based on existing literature. The translation-back-translation method was used to produce a conceptually equivalent Chinese version (Flynn et al., 2010). To ensure content validity, the questionnaire was pilot-tested using a sample of 15 manufacturing firms in China through face-to-face discussion. The wording of some questions was modified to ensure that the items were understandable and relevant to practices used in China (Flynn et al., 2010). One key informant per firm method was adopted to fill out a questionnaire. The informants included senior managers such as general managers and directors, research and development (R\&D) managers, operations and manufacturing managers, and supply chain and purchasing managers.

A professional market research firm was hired to collect the data (Cai et al., 2010). The researchers designed the sampling framework and data collection instruction that 
direct the professional interviewers of the market research firm in data collection. The professional interviewers were also trained to ensure the reliable and complete response. Before large sample data collection, the professional market research firm selected 10 companies in each regions to test the survey. The questionnaire, sampling framework, and data collection instruction are also amended based on the feedbacks. From the target regions, 2379 manufacturing firms were randomly selected using the directory provided by the National Bureau of Statistics of the People's Republic of China, which is an agency within the state council charged with the collection and publication of statistics related to the economy of China at national and local levels. The market research firm first contacted the target manufacturers by telephone to confirm that the informant would be able to answer the survey questions and to solicit his or her participation in the study. Among the target sample, 2061 manufacturing firms either could not be contacted due to incorrect contact information or declined to participate in the survey. Then professional interviewers from the market research firm were sent to visit the remaining 318 manufacturers and collect data using a face-to-face interviews. Finally, 300 responses were received, resulting in a response rate of $12.6 \%$. Table 1 shows the profiles of the responding firms.

Insert Table 1 here

\subsection{Measures}

Institutional support, dysfunctional competition, product and process innovation, and firm performance were assessed using multiple items on a 7-point Likert-type scale. The scales were adopted or adapted from previous studies and are listed in Table 2. Institutional support was measured using four items to gauge the favorable policies and programs, technical and financial resources, and permission for business actions obtained from the government and its agencies (Li and Atuahene-Gima, 2001). Dysfunctional competition was measured using four items to capture the managers' perceptions of opportunistic, unfair, and unlawful activities in their principal industry (Li and Atuahene-Gima, 2001). Product innovation was measured using three items covering the speed and frequency of new product development, and process 
innovation was measured using four items covering the speed and frequency of new process development. These were adapted from Parasuraman (2000) and Tellis et al. (2009). Firm performance was measured using four items covering profit, market share, and sales. These were adapted from Qi et al. (2011) and Gunday et al. (2011).

$\mathrm{R} \& \mathrm{D}$ investment and new process investment served as control variables because direct investment can improve product and process innovation (Shu et al., 2015). This study also controlled for the number of employees and ownership because large and state-owned firms may have more advantages in accessing resources and institutional support than smaller, private operations ( $\mathrm{Li}$ and Atuahene-Gima, 2001; Sheng et al., 2013).

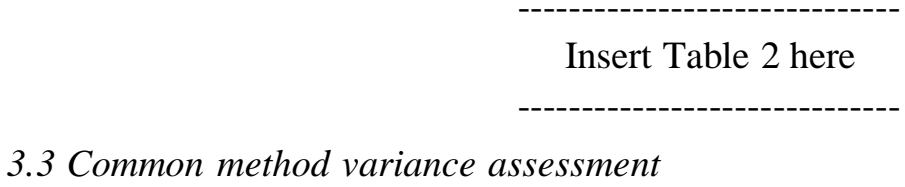

Because there was a single respondent from each firm, common method variance (CMV) was a potential issue. According to Podsakoff et al. (2003), appropriate arrangement of items in a questionnaire can reduce CMV. The constructs were arranged in different sections of the questionnaire. Different instructions were used for different scales (Table 2). Such questionnaire design can reduce respondents' potential consistency in self-reporting (Podsakoff et al., 2003). We conducted a Harman's single-factor test including all items using exploratory factor analysis (Podsakoff et al., 2003). There was no evidence of CMV because no single factor accounted for most of the covariance. In addition, the correlation matrix (Table 3) shows that the strongest correlation was 0.557 . The lack of excessively strong correlations also indicates that CMV is not a serious concern (Pavlou et al., 2007).

\section{Analysis and results}

Partial least squares (PLS)-based structural equation modeling is used to test this the research model because of the sample size (Peng and Lai, 2012). SmartPLS software (3.2.1 version) is used to assess the measurement and structural models 
(Ringle et al., 2015). A bootstrapping estimation procedure is used to examine the significance of the scale factor loadings in the measurement model and that of the path coefficients in the structural model (Peng and Lai, 2012; Wang et al., 2010).

\subsection{Measurement model}

We employ Cronbach's alpha and composite reliability to assess the reliability of all the constructs. The values of Cronbach's alpha and composite reliability range from 0.773 to 0.855 and from 0.858 to 0.902 , respectively (Table 2 ). These values are all above the recommended threshold value of 0.70 (Nunnally and Bernstein, 1994), suggesting that all constructs are reliable.

Confirmative factor analysis (CFA) and average variance extracted (AVE) are used to assess the convergent and discriminant validity. All of the AVE values range from 0.604 to 0.697 (Table 2), which are above the recommended value of 0.50 . The CFA analysis shows that the loadings of all items but one are above 0.7 (ranging from 0.662 to 0.873$)$. Both tests indicate adequate convergent validity for all constructs (Fornell and Larcker, 1981; Henseler et al., 2009).

Discriminant validity is assessed by comparing the square root of each construct's AVE to its correlation coefficients with other constructs. A square root higher than the correlation with other constructs suggests a satisfied discriminant validity (Fornell and Larcker, 1981). Table 3 shows the mean and standard deviations of the constructs and their correlations. Comparison of all the correlations and square roots of the AVEs on the diagonal indicates adequate discriminant validity of all constructs.

Insert Table 3 here

\subsection{Structural model and hypotheses testing}

The assessment of PLS models involves estimation of the path loadings and $\mathrm{R}^{2}$ values (Wang et al., 2010). Path loadings indicate the strength of the relationships between independent and dependent variables, and $\mathrm{R}^{2}$ values indicate predictive power by showing the amount of variance explained by the independent variables (Peng and Lai, 2012). Results of the structural model using the pooled sample are 
shown in Figure 2. Since the objective of PLS is to maximize variance explained, therefore $\mathrm{R}^{2}$ as a prediction oriented measure is used to evaluate PLS models. The model explains $29.3 \%$ of variance in firm performance, $11.4 \%$ of variance in product innovation, and $19.4 \%$ of the variance in process innovation. The standardized root mean square residual (SRMR) is used to measure the goodness of model fit. It assesses the average magnitude of the discrepancies between observed and expected correlations as an absolute measure of model fit criterion (Henseler et al., 2014). Our results show that SRMR values of total sample, low dysfunctional competition sample, and high dysfunctional competition sample were $0.039,0.045$, and 0.051 , respectively. All SRMR values are less than 0.08 indicating a satisfactory model fit. Following Wetzels et al. (2009), the global goodness of fit (GoF) is also calculated. Out results show that GoF of total sample, low dysfunctional competition sample, and high dysfunctional competition sample are $0.371,0.483$, and 0.295 , respectively, which indicates a satisfactory model.

The results show that institutional support has significant effects on product innovation ( $\mathrm{b}=0.300, P<0.001)$, process innovation $(\mathrm{b}=0.433, P<0.001)$, and firm performance $(b=0.215, P<0.001)$. Product innovation $(b=0.199, P<0.05)$ and process innovation $(\mathrm{b}=0.209, P<0.01)$ are found to positively affect firm performance. These findings provide support for $\mathrm{H} 1 \mathrm{a}, \mathrm{H} 1 \mathrm{~b}, \mathrm{H} 2, \mathrm{H} 3 \mathrm{a}$, and $\mathrm{H} 3 \mathrm{~b}$. The results also show that firm size and type of ownership significantly influence firm performance and that the effects of $R \& D$ investment and new process investment on product and process innovation are insignificant.

Insert Figure 2 here

Following Koufteros et al. (2005), two groups are formed based on the mean score on dysfunctional competition. Firms scoring below the mean score are classified as belonging to the low group and those scoring above are placed in the high group. There are 162 manufacturing firms in the group with high levels of dysfunctional 
competition and 138 in the low group. A non-parametric approach, PLS based multi-group analysis (PLS-MGA), is used here to investigate the moderating effects of dysfunctional competition (Henseler et al., 2009). The bootstrap estimates of the structural model based on two sub-samples are shown in Figure 3. Results of the comparison are shown in Table 4 . The findings show that, at the 5\% probability of error level, the effects of institutional support on product $(\triangle=0.375, P=0.000)$ and process $(\triangle=0.162, P=0.043$ ) innovation are significantly larger in the low dysfunctional competition group, and the effects of institutional support, product innovation, and process innovation on firm performance are not statistically different in the two groups. In this way, the results indicate that dysfunctional competition negatively moderates the effects of institutional support on product and process innovation but does not influence the effects of institutional support, product innovation, and process innovation on firm performance. Therefore, the findings support $\mathrm{H} 4 \mathrm{a}$ and $\mathrm{H} 4 \mathrm{~b}$, but not $\mathrm{H} 4 \mathrm{c}, \mathrm{H} 4 \mathrm{~d}$, or $\mathrm{H} 4 \mathrm{e}$.

Insert Figure 3 and Table 4 here

\section{Discussion and conclusions}

\subsection{Theoretical contributions}

This study contributes to both innovation and institution-based view literature. First, the results indicate that institutional support positively affects product and process innovation and firm performance. These findings are consistent with existing empirical evidence regarding the performance outcomes of institutional support (e.g. Cai et al., 2010; Li and Atuahene-Gima, 2001; Guo et al., 2014; Shu et al., 2015) and confirm the importance of the government and its agencies in promoting innovation and business development in China. This may explain why Chinese manufacturers are investing more in innovation despite the underdeveloped institutional environment (Zhou and Poppo, 2010; Zhang et al., 2015). PLS analysis further reveals that institutional support improves firm performance indirectly via product and process innovation (indirect effect $=0.150, P=0.000$ ). These findings provide insights into the 
complex relationships among institutional support, innovation, and performance. By revealing that support from the government can improve firm performance both directly and indirectly by promoting product and process innovation, this study clarifies the mechanisms through which institutional support provides firms with competitive advantages and how Chinese government officials influence their operations and decisions. It also explains how institutions matter ( $\mathrm{Li}$ and Atuahene-Gima, 2001; Shu et al., 2015; Qian et al., 2013; Sheng et al., 2011), so contributing to the institution-based view literature (Peng et al., 2009).

Second, we find that both product and process innovation enhance firm performance, which is consistent with existing empirical findings (Walker, 2004; Kostopoulos et al., 2011; Gunday et al., 2011; Ho, 2011). These results contribute to the innovation literature by confirming the positive roles played by product and process innovation in improving firm performance in China. They provide a possible explanation for the rapid growth in the number of patent applications filed in China (World Intellectual Property Organization, 2015). In addition, although researchers argue that product and process innovation have different features (Un and Asakawa, 2015; Damanpour, 2010) and there is some empirical evidence that they influence performance outcomes in different ways (Gunday et al., 2011; Shu et al., 2015), this study provides empirical evidence that product and process innovation play similar roles in improving firm performance in China and that the Chinese government can promote product and process innovation using similar methods, contributing to the innovation literature.

Third, this study reveals the contingent effects of dysfunctional competition on the effectiveness of institutional support. In particular, results show that dysfunctional competition attenuates the impact of institutional support on product and process innovation. This provides one possible explanation for the inconsistent empirical findings on the performance outcomes of institutional support (Cai et al., 2010; Sheng et al., 2011; Shu et al., 2015). The results improve current understanding of how dysfunctional competition affects manufacturers' innovation decisions, contributing to the innovation literature (Qian et al., 2013; Guo et al., 2014). The results also show 
that China's institutional environment has both positive and negative influences on product and process innovation and that researchers must consider the effects of different institutional forces collectively when investigating the roles of institutional environment in China ( $\mathrm{Li}$ and $\mathrm{Li}, 2009$; $\mathrm{Li}$ and Zhang, 2007). In addition, the findings enrich the institution-based view literature by clarifying under what circumstances institutions matter (Peng, 2002; Peng et al., 2009).

Fourth, the results show that dysfunctional competition does not moderate the effects of institutional support, product innovation, and process innovation on firm performance. This is an interesting finding as it suggests that although dysfunctional competition reduces the positive effects of institutional support on innovation, firms can still benefit from institutional support and from product and process innovation. The characteristics of innovation in China might be the reason for this seemingly contradictory findings. Although the Chinese government seeks to promote independent innovation (Parayil and D’Costa, 2009), Chinese manufacturers tend to develop products and processes by imitating and adapting existing technologies to unique local requirements (Wang et al., 2011; Zhang et al., 2015). In this way, product and process innovation rely on refining, broadening, enhancing, and exploiting current knowledge and skills. Dysfunctional competition encourages knowledge spillovers and firms are less likely to be punished for copying and reverse engineering existing products and processes than they are in developed countries ( $\mathrm{Li}$ and Atuahene-Gima, 2001; Guo et al., 2014). Chinese manufacturers may profit from the innovations that are developed by adapting and localizing competitors' product and process designs when dysfunctional competition is intense (Zhang et al., 2015). In addition, manufacturing firms may decide to use government support in areas that are less likely influenced by dysfunctional competition, such as expanding production capacity or investing abroad, instead of on innovation. Hence, they can benefit from institutional support even when dysfunctional competition is intense. Therefore, this study contributes to the institution-based view literature by showing that dysfunctional competition affects innovation and firm performance in different ways in China. 


\subsection{Managerial implications}

The findings of this study can provide guidelines to help manufacturing firms take advantage of China's institutional environment and gain competitive advantages. First, we suggest managers build personal ties with political leaders and officials in industrial bureaus and regulatory and supporting organizations. Firms should actively seek support from the government and its agencies and understand that they are particularly important resources that they can use to deal with China's institutional voids. Managers should use institutional support in product and process innovation and to improve operations. Second, we suggest firms invest in product and process innovation simultaneously because both of them can provide competitive advantages. In particular, it is suggested that firms learn new product and process designs produced by advanced competitors. They should also attend conferences and exhibitions to keep up with the product and process innovation in the industry. Managers should invest in improving the speed and frequency of new product and process development. Third, managers should be aware that dysfunctional competition influences innovation and firm performance in different ways. They should carefully evaluate the legal and competitive environment. When dysfunctional competition is intense, firms should reduce their efforts to acquire institutional support for product and process innovation. However, we suggest Chinese manufacturers invest in product and process innovation and use institutional support to improve operations even when dysfunctional competition is intense.

This study also has valuable implications for policy makers. Promoting innovation and development has become a major issue for the Chinese government and its agencies and the findings reveal that institutional support is a useful way for government officials to influence firms' decisions and operations. In particular, we suggest government officials devise policies and programs that reward product and process innovation. Technical and financial resources should be provided to support innovation and operations in manufacturing firms. Officials should also help firms obtain licenses to import technology and other equipment. In addition, officials should be aware that the effects of institutional support on product and process innovation are 
reduced by dysfunctional competition. Hence, government and its agencies should reduce dysfunctional competition to allow firms to fully reap the benefits of institutional support. In particular, we suggest policy makers to develop laws regulating market competition to protect intellectual property rights and improve the enforcement of existing laws to punish unfair and unlawful practices, such as illegal copying of new products and counterfeiting of products and trademarks.

\subsection{Limitations and future research directions}

This study has several limitations that open up avenues for future research. First, it focuses on two characteristics of China's institutional environment. Researchers argue that other institutional forces, such as legal enforceability (Zhou and Poppo, 2010), legal protection (Cai et al., 2010), and regulatory legitimacy (Guo et al., 2014), also influence Chinese firms' operations and strategies. Future studies may investigate the joint effects of different kinds of institutional forces on firms' innovation decisions. Second, institutional support consists of many factors, such as R\&D investment, professional services, and loans, which may influence innovation and operations in different ways. Future studies can investigate the effects of different types of institutional support on firm performance. Third, our results provide insight into how institutions matter in China. Researchers argue that the effects of institutional forces may be influenced by cultural environment ( $\mathrm{Li}$ and Atuahene-Gima, 2001; Cai et al., 2010). Future studies can generalize and validate these findings into other countries with different institutional and cultural environments. Fourth, this study measures firm performance using a Likert-type scale, which is based on managers' perceptions and may be influenced by respondents' personal opinions. Future studies can measure firm performance using objective measures and ratio scales, such as market share. 


\section{References}

Cai, S., Jun, M. and Yang, Z. (2010), "Implementing supply chain information integration in China: The role of institutional forces and trust", Journal of Operations Management, Vol. 28 No. 3, pp. 257-268.

Damanpour, F. (2010), "An integration of research findings of effects of firm size and market competition on product and process innovations", British Journal of Management, Vol. 21 No. 4, pp. 996-1010.

Flynn, B.B., Huo, B. and Zhao, X. (2010), "The impact of supply chain integration on performance: A contingency and configuration approach", Journal of Operations Management, Vol. 28 No. 1, pp. 58-71.

Fornell, C. and Larcker, D.F. (1981), "Evaluating structural equation models with unobservable variables and measurement errors", Journal of Marketing Research, Vol. 18 No. 1, pp. 39-50.

Fuentelsaz, L., Garrido, E. and Maicas, J. P. (2015), "Incumbents, technological change and institutions: How the value of complementary resources varies across markets", Strategic Management Journal, Vol. 36 No. 12, pp. 1778-1801.

Gunday ,G., Ulusoy, G., Kilic, K. and Alpkan, L. (2011), "Effects of innovation types on firm performance", International Journal of Production Economics, Vol. 133 No. 2, pp. 662-676.

Guo, H., Xu, E. and Jacobs, M. (2014), "Managerial political ties and firm performance during institutional transitions: An analysis of mediating mechanisms", Journal of Business Research, Vol. 67 No. 2, pp. 116-127.

Henseler, J., Dijkstra, T. K., Sarstedt, M., Ringle, C. M., Diamantopoulos, A., Straub, D. W., Ketchen, D. J., Hair, J. F., Hult, G. T. M., and Calantone, R. J. (2014), "Common beliefs and reality about Partial Least Squares: Comments on Rönkkö \& Evermann (2013)”, Organizational Research Methods, Vol. 17 No. 2, pp. 182-209.

Henseler, J., Ringle, C. M. and Sinkovics, R. R. (2009), "The use of Partial Least Squares path modeling in international marketing", Advances in International Marketing, Vol. 20 No. 1, pp. 277-320.

Ho, L. (2011), "Meditation, learning, organizational innovation and performance", Industrial Management \& Data Systems, Vol. 111, No.1, pp.113-131.

Kuo, Y. (2013) "Technology readiness as moderator for construction company performance", Industrial Management \& Data Systems, Vol. 113, No.4, pp.558 572.

Li, H. and Atuahene-Gima, K. (2001), "Product innovation strategy and the performance of new technology ventures in China", Academy of Management Journal, Vol. 44 No. 6, pp. 1123-1134.

Li, H. and Li, J. (2009), "Top management team conflict and entrepreneurial strategy making in China", Asia Pacific Journal of Management, Vol. 26 No. 2, pp. 263-283.

Li, H. and Zhang, Y. (2007), "The role of managers' political networking and functional experience in new venture performance: Evidence from China's transition economy", Strategic Management Journal, Vol. 28 No. 8, pp. 791-804.

Lu, Y., Tsang, E. W. K. and Peng, M. W. (2008), "Knowledge management and 
innovation strategy in the Asia pacific: Toward an institution-based view", Asia Pacific Journal of Management, Vol. 25 No. 3, pp. 361-374.

Lu, K., Zhu, J. and Bao, H. (2015), "High-performance human resource management and firm performance", Industrial Management \& Data Systems, Vol. 115 No. 2, pp. 353-382.

Kostopoulos, K., Papalexandris, A., Papachroni, M. and Ioannou, G. (2011), "Absorptive capacity, innovation, and financial performance", Journal of Business Research, Vol. 64 No. 12, pp. 1335-1343.

Koufteros, X., Vonderembse, M. and Jayaram, J. (2005), "Internal and external integration for product development: The contingency effects of uncertainty, equivocality, and platform strategy", Decision Sciences, Vol. 36 No. 1, pp. 97-133.

Ma, Z., Yu, M., Gao, C., Zhou, J. and Yang, Z. (2014), "Institutional constraints of product innovation in China: Evidence from international joint ventures", Journal of Business Research, Vol. 68 No. 5, pp. 949-956.

Morgan, R. E. and Berthon, P. (2008), "Market orientation, generative learning, innovation strategy and business performance inter-relationships in bioscience firms", Journal of Management Studies, Vol. 45 No. 8, pp. 1329-1353.

Nunnally, J. C. and Bernstein, I. H. (1994), Psychological theory, New York, McGraw-Hill.

National Bureau of Statistics (2014), Statistical communique of national science and technology investment in 2014, Ministry of Science and Technology and Ministry of Finance, Beijing

Parasuraman, A. (2000), “Technology Readiness Index (TRI) a multiple-item scale to measure readiness to embrace new technologies", Journal of service research, Vol. 2 No. 4, pp. 307-320.

Parayil, G. and D'Costa, A.P. (2009), The new Asian innovation dynamics: China and India in perspective, England, Palarave Macmillan

Pavlou, P.A., Liang, H. and Xue, Y. (2007), "Understanding and mitigating uncertainty in online exchange relationships: A principal-agent perspective", MIS Quarterly, Vol. 31 No. 1, pp. 105-136.

Peng, D. X. and Lai, F. (2012), "Using partial least squares in operations management research: A practical guideline and summary of past research", Journal of Operations Management, Vol. 30 No. 6, pp. 467-480.

Peng, M. W. (2002), "Towards an institution-based view of business strategy", Asia Pacific Journal of Management, Vol. 19 No. 2, pp. 251-267.

Peng, M. W. (2003), "Institutional transitions and strategic choices", Academy of Management Review, Vol. 28 No. 2, pp. 275-296.

Peng, M. W. (2006), Global strategy, Cincinnati, OH: South-Western Thomson.

Peng, M. W. (2013), “An institution-based view of IPR protection”, Business Horizons, Vol. 56 No. 2, pp. 135-139.

Peng, M. W., Sun, S. L., Pinkham, B. and Chen, H. (2009), "The institution-based view as a third leg for a strategy tripod", The Academy of Management Perspectives, Vol. 23 No. 3, pp. 63-81.

Peng, M. W., Wang, D. and Jiang, Y. (2008), “An institution-based view of 
international business strategy: A focus on emerging economies", Journal of International Business Studies, Vol. 39 No. 5, pp. 920-936.

Podsakoff, P. M., MacKenzie, S. B., Lee, J. Y. and Podsakoff, N. P. (2003), "Common method biases in behavioral research: a critical review of the literature and recommended remedies", Journal of applied psychology, Vol. 88 No. 5, pp. 879-903.

Qi, Y., Zhao, X. and Sheu, C. (2011), "The impact of competitive strategy and supply chain strategy on business performance: The role of environmental uncertainty", Decision Sciences, Vol. 42 No. 2, pp. 378-89.

Qian, C., Cao, Q. and Takeuchi, R. (2013), “Top management team functional diversity and organizational innovation in China: The moderating effects of environment", Strategic Management Journal, Vol. 34 No. 1, pp. 110-120.

Ringle, C.M., Wende, S. and Becker, J.M. (2015), "SmartPLS 3." Boenningstedt: SmartPLS GmbH, http://www.smartpls.com.

Ruiz-Jiménez, J. M. and Fuentes-Fuentes, M. (2013), "Knowledge combination, innovation, organizational performance in technology firms", Industrial Management \& Data Systems, Vol. 113 No. 4, pp. 523-540.

Sarstedt, M., Henseler, J. and Ringle, C. M. (2011), "Multi-group analysis in Partial Least Squares (PLS) path modeling: Alternative methods and empirical results", Advances in International Marketing, Vol. 113 No. 4, pp.195-218.

Schoenherr, T. and Swink, M. (2015), "The roles of supply chain intelligence and adaptability in new product launch success", Decision Sciences, Vol. 46 No. 5, pp. 901-936.

Sheng, S., Zhou, K. Z. and Lessassy, L. (2013), "NPD speed vs. innovativeness: The contingent impact of institutional and market environments", Journal of Business Research, Vol. 66 No. 11, pp. 2355-2362.

Sheng, S., Zhou, K. Z. and Li, J. J. (2011), "The effects of business and political ties on firm performance: Evidence from China", Journal of Marketing, Vol. 75 No. 1, pp. $1-15$.

Shu, C., Wang, Q., Gao, S. and Liu, C. (2015), "Firm patenting, innovations, and government institutional support as a double-edged sword", Journal of Product Innovation Management, Vol. 32 No. 2, pp. 290-305.

Tellis, G. J., Prabhu, J. C. and Chandy, R. K. (2009), "Radical innovation across nations: The preeminence of corporate culture", Journal of Marketing, Vol. 73 No. 1, pp. 3-23.

Un, C. A. and Asakawa, K. (2015), "Types of R\&D collaborations and process innovation: The benefit of collaborating upstream in the knowledge chain", The Journal of Product Innovation Management, Vol. 32 No. 1, pp.138-153.

Walker, R. M. (2004), "Innovation and organizational performance: A critical review and research agenda", In Best Papers Proceedings from the Academy of Management Meeting, Honolulu, 5-10 August.

World Intellectual Property Organization, (2015), WIPO IP facts and figures (2015 edition), WIPO Publication, No. 943E/14.

Wang, L., Yeung, J.H.Y., and Zhang, M. (2011), "The impact of trust and contract on 
innovation performance: The moderating role of environmental uncertainty", International Journal of Production Economics, Vol 134 No.1, pp.114-122.

Wang, Q., Huo, B., Lai, F., Chu, Z. (2010), "Understanding performance drivers of third - party logistics providers in mainland China: A replicated and comparative study", Industrial Management \& Data Systems, Vol. 110 No 9, pp.1273 - 1296.

Wang, Z., Huo, B., Tian, Y., Hua, Z. (2015), "Effects of external uncertainties and power on opportunism in supply chains: Evidence from China", International Journal of Production Research, Vol. 53, No. 20, pp. 6294-6307.

Wetzels, M., Odekerken-Schröder, G., and Van Oppen, C. (2009), "Using PLS path modeling for assessing hierarchical construct models: Guidelines and empirical illustration", MIS Quarterly, Vol. 33, No. 1, pp. 177-195.

Zhao, M. (2006), "Conducting R\&D in countries with weak intellectual property rights protection”, Management Science, Vol. 52 No. 8, pp. 1185-1199.

Zhou, K. Z. and Poppo, L. (2010), "Exchange hazards, relational reliability, and contracts in china: The contingent role of legal enforceability", Journal of International Business Studies, Vol. 41 No. 5, pp. 861-881.

Zhang, M., Zhao, X., Voss, C., and Zhu, G. (2015), "Innovating through services, co-creation and supplier integration: Cases from China", International Journal of Production Economics DOI: 10.1016/j.ijpe.2015.09.026 
Table 1: Firm profiles

\begin{tabular}{|c|c|c|c|}
\hline Variables & & Num. & Percentage \\
\hline \multirow{8}{*}{$\begin{array}{l}\text { Annual sale } \\
\text { (USD) }\end{array}$} & Fewer than 1 million & 1 & 0.3 \\
\hline & 1 to 5 million & 12 & 4.0 \\
\hline & 5 to 10 million & 27 & 9.0 \\
\hline & 10 to 20 million & 59 & 19.7 \\
\hline & 20 to 50 million & 88 & 29.3 \\
\hline & 50 to 100 million & 51 & 17.0 \\
\hline & 100 to 250 million & 36 & 12.0 \\
\hline & More than 250 million & 26 & 8.7 \\
\hline \multirow{5}{*}{$\begin{array}{l}\text { Number of } \\
\text { employees }\end{array}$} & Fewer than 200 & 67 & 22.3 \\
\hline & 201 to 300 & 56 & 18.7 \\
\hline & 301 to 500 & 69 & 23.0 \\
\hline & 501 to 1000 & 52 & 17.3 \\
\hline & 1000 or more & 56 & 18.7 \\
\hline \multirow{4}{*}{ Ownership } & State-owned & 96 & 32.0 \\
\hline & Privately owned & 102 & 34.0 \\
\hline & Joint venture & 46 & 15.3 \\
\hline & Foreign investment & 56 & 18.7 \\
\hline \multirow{8}{*}{ Industry } & Biology and pharmaceuticals & 18 & 6.0 \\
\hline & Computers and telecommunication equipment & 34 & 11.3 \\
\hline & Chemicals & 51 & 17.0 \\
\hline & Medical equipment & 28 & 9.3 \\
\hline & Electronics and electrical equipment & 54 & 18.0 \\
\hline & Industrial machinery & 49 & 16.3 \\
\hline & I ransportation equipment & 30 & 11.1 \\
\hline & New materials & 31 & 10.3 \\
\hline Total & & 300 & 100.0 \\
\hline
\end{tabular}

Table 2: Factor loadings of scale items (CFA factor loading)

\begin{tabular}{|c|c|}
\hline Measurement & Loading \\
\hline competition $\quad$ (Cronbach's $\quad \alpha=0.787 ; \quad$ C.R. $=0.858$ & \\
\hline $\begin{array}{l}\text { Please indicate the extent to which your principal industry has experienced } \\
\text { the following in the last } 3 \text { years: }(1=\text { not at all, } 7=\text { to a great extent })\end{array}$ & \\
\hline $\begin{array}{l}\text { 1. Unlawful competitive practices such as illegal copying of new products. } \\
\text { 2. Counterfeiting of your company's own products and trademarks by other } \\
\text { companies. }\end{array}$ & $\begin{array}{l}0.825^{* * *} \\
57 \\
\text { intell }\end{array}$ \\
\hline
\end{tabular}

3. Ineffective market competitive laws to protect your company's 

Institutional support (Cronbach's $\alpha=0.855 ; C . R .=0.902 ;$ AVE $=0.697$ )

Please indicate the extent to which in the last three years government and its agencies have: ( $1=$ not at all, $7=$ to a great extent)

1. Implemented policies and programs that have been beneficial to your company's operations.

2. Provided needed technology information and technical support to your company.

3. Played a significant role in providing financial support for your company.

4. Helped your company to obtain licenses to import technology, 0.778 manufacturing and other equipment.

Product innovation (Cronbach's $\alpha=0.773$; C.R. $=0.868$; AVE $=0.687$ )

Please indicate your degree of agreement with the following statements describing your company's product innovation: ( $1=$ strongly disagree, $7=$ strongly agree)

1. We are the first within the industry to introduce new products.

2. We keep up with the latest product developments.

3. We frequently introduce products that are radically different from 0.832 established products in the industry.

Process innovation (Cronbach's $\alpha=0.845$; C.R. $=0.896$; AVE=0.684)

Please indicate your degree of agreement with the following statements describing your company's manufacturing process innovation: ( $1=$ strongly disagree, $7=$ strongly agree)

1. We are learning more about the newest processes than our competitors.

2. We are the first within the industry to deploy new processes.

3. We keep up with the latest process developments.

4. We frequently introduce processes that are radically different from existing processes in the industry.

Firm performance (Cronbach's $\alpha=0.843$; C.R. $=0.895$; AVE $=0.681$ )

Please indicate your firm's overall performance compared with major competitors over the past year on: (1=far worse, $7=$ far better $)$

1. Total sales of product and service

2. Profit

3. Market share

4. Market share growth

R\&D investment: Over the last two years, what was your average research and development $(R \& D)$ budget as a percentage of total company sales?

New process investment: Over the last two years, what was your average investment in new process technologies and equipment as a percentage of total company sales?

Firm size: The total number of employees.

Ownership: The ownership of your company 
Table 3. Mean, standard deviation, and correlations

\begin{tabular}{lrrrrrrr}
\cline { 2 - 8 } Constructs & Mean & SD & \multicolumn{1}{c}{1} & \multicolumn{1}{c}{2} & \multicolumn{1}{c}{3} & 4 & 5 \\
\cline { 2 - 8 } Institutional support (1) & 4.526 & 1.428 & $\mathbf{0 . 8 3 5}$ & & & & \\
Dysfunction competition (2) & 4.205 & 1.286 & 0.013 & $\mathbf{0 . 7 7 7}$ & & & \\
Product innovation (3) & 5.300 & 1.005 & $0.300^{* * *}$ & $0.249^{* * *}$ & $\mathbf{0 . 8 2 9}$ & & \\
Process innovation (4) & 5.098 & 1.013 & $0.428^{* * *}$ & 0.119 & $0.557^{* * *}$ & $\mathbf{0 . 8 2 7}$ & \\
Firm performance (5) & 4.769 & 1.035 & $0.389^{* * *}$ & 0.042 & $0.396^{* * *}$ & $0.431^{* * * *}$ & $\mathbf{0 . 8 2 5}$ \\
\hline
\end{tabular}

Note: $* P<0.05, * * P<0.01$, *** $P<0.001$. Square root of average variance extracted for each construct included in the model is given in bold along the diagonal in the table.

Table 4: Statistical comparison of path coefficients between low and high levels of dysfunctional competition

\begin{tabular}{|c|c|c|c|c|c|c|}
\hline & \multicolumn{2}{|c|}{ Low } & \multicolumn{2}{|c|}{ High } & \multicolumn{2}{|c|}{ Low vs. High } \\
\hline & $\begin{array}{l}\text { Path } \\
\text { coefficient }\end{array}$ & SE & $\begin{array}{c}\text { Path } \\
\text { coefficient }\end{array}$ & SE & $\mathrm{ABS}$ & $P$-value \\
\hline \multicolumn{7}{|l|}{ Institutional support $\rightarrow$} \\
\hline product innovation & 0.475 & 0.067 & 0.101 & 0.084 & 0.375 & $0.000 * * *$ \\
\hline $\begin{array}{l}\text { Institutional support } \rightarrow \\
\text { process innovation }\end{array}$ & 0.507 & 0.061 & 0.345 & 0.076 & 0.162 & $0.043 *$ \\
\hline $\begin{array}{l}\text { Institutional support } \rightarrow \\
\text { firm performance }\end{array}$ & 0.227 & 0.072 & 0.226 & 0.073 & 0.001 & 0.496 \\
\hline $\begin{array}{l}\text { Product innovation } \\
\rightarrow \text { firm performance }\end{array}$ & 0.203 & 0.103 & 0.168 & 0.084 & 0.035 & 0.398 \\
\hline $\begin{array}{l}\text { Process innovation } \rightarrow \text { firm } \\
\text { performance }\end{array}$ & 0.254 & 0.099 & 0.146 & 0.094 & 0.108 & 0.216 \\
\hline
\end{tabular}

Note: $* P<0.05, * * P<0.01, * * * P<0.001$. ABS means the absolute value of difference. 
57

58

59

60

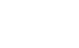

.


Figure 1: Conceptual model
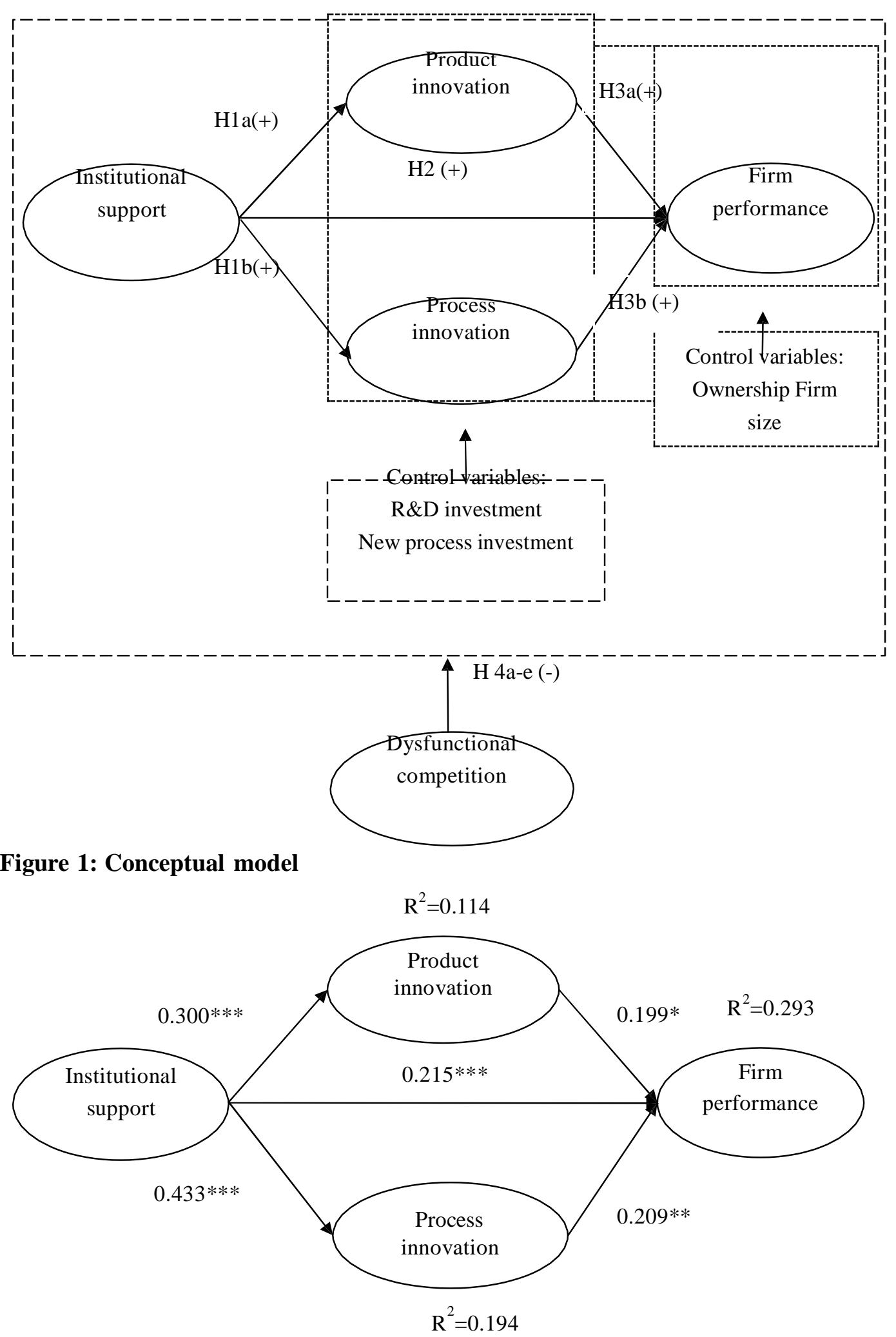

Note: $* P<0.05 ; * * P<0.01 ; * * * P<0.001$

Figure 2: Structural model with parameter estimates (pooled sample) 


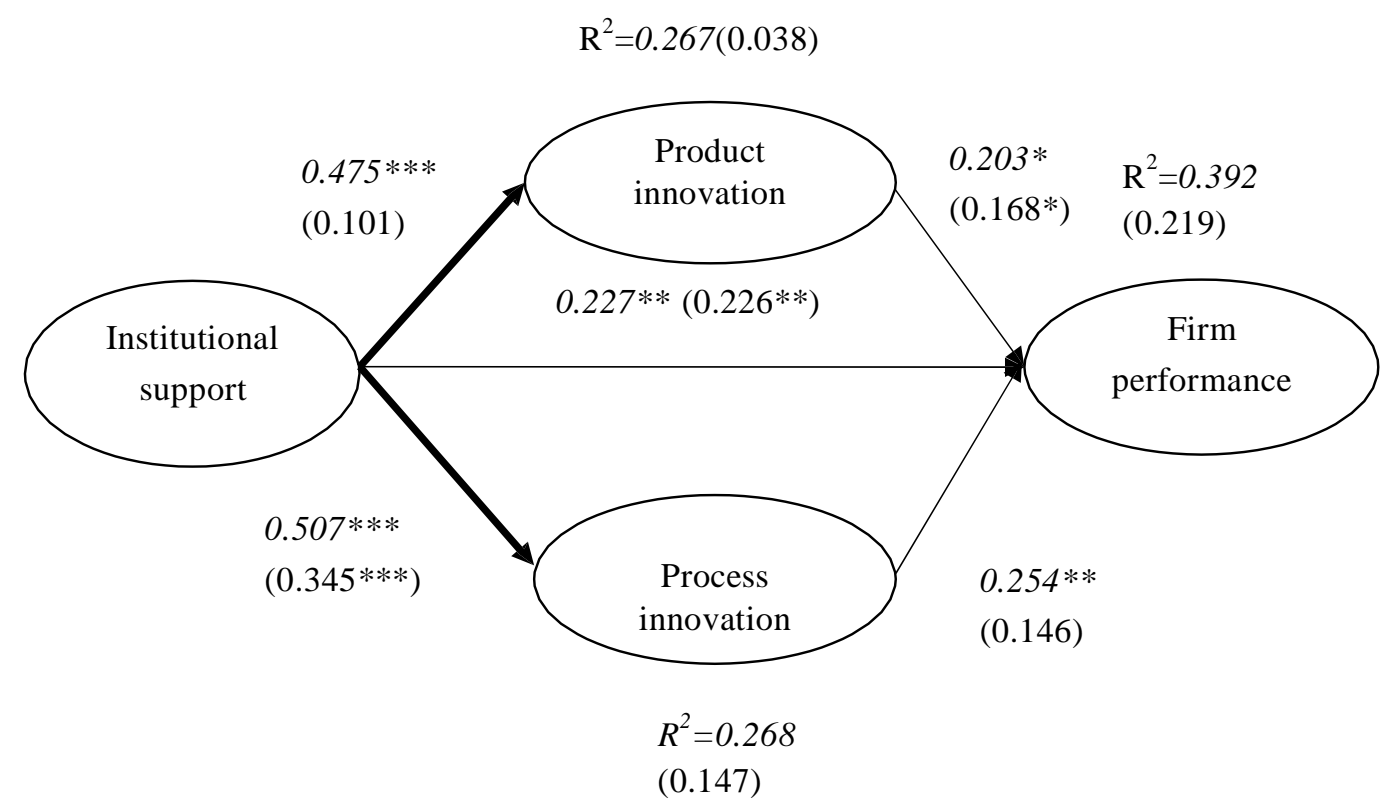

Note: $* P<0.05$;** $P<0.01$; *** $P<0.001$. The results in the group subject to low (high) levels of dysfunctional competition are shown in italic (parentheses). The bold lines indicate that the path coefficients are significantly different between the two groups at a confidence level of 0.05 .

Figure 3: The moderating effects of dysfunctional competition 
55

56

57

58

59 